\title{
An alternative method to convert fractured metal ceramic surveyed crown into a complete contour zirconia surveyed crown using CAD- CAM technology under anticancer treatments: a clinical report
}

\author{
Seon-Ki Lee ${ }^{1}$, Hong-So Yang', Sang-Won Park ${ }^{1,2}$, Kwi-Dug Yun', Hyun-Pil Lim* \\ 'Department of Prosthodontics, School of Dentistry, Chonnam National University, Gwangju, Republic of Korea \\ ${ }^{2}$ RIS Foundation for Advanced Biomaterials, School of Dentistry, Chonnam National University, Gwangju, Republic of Korea
}

In this clinical report, a simple and convenient conversion of a fractured metal-ceramic surveyed crown into a complete contour zirconia surveyed crown by using computer-aided design and computer-aided manufacturing technology for an existing partial removable dental prosthesis is described. The duplication of the original contours, morphology, and the rest seat of the existing metal-ceramic surveyed crown, into a complete contour zirconia surveyed crown under anticancer treatments were reported. (J Dent Rehabil Appl Sci 2015;31(1):45-9)

Key words: complete contour zirconia surveyed crown; fractured metal-ceramic surveyed crown; computer-aided manufacturing and computer-aided manufacturing (CAD/CAM) technology; existing partial removable dental prosthesis; anticancer treatments

\section{Introduction}

Although partial removable dental prosthesis (PRDP) is one of the most reasonable treatment modalities in prosthodontics, secondary caries on abutment are still a concern. If secondary caries are detected and PRDP is clinically accepted, retrofitted surveyed crown is needed. Not only direct techniques but also indirect techniques were introduced to fabricate a retrofit surveyed crown for an existing PRDP. ${ }^{1-4}$ However, replicating original contours, morphology, rest seats, and guiding plane of the previous abutment were not easy.

With the development of computer-aided design and computer-aided manufacturing (CAD/CAM) technology and with their enhanced application in

*Correspondence to: Hyun-Pil Lim

Associate Professor, Department of Prosthodontics, School of Dentistry, Chonnam National University, 33 Yongbong-ro, Buk-gu, Gwangju, 500-757, Republic of Korea

Tel: +82-62-530-5577, Fax: +82-62-530-5639, E-mail: mcnihil@jnu.ac.kr

Received: October 6, 2014/Last Revision: March 2, 2015/Accepted: March 5, 2015 dentistry, Marchack et al. introduced the fabrication of an all-ceramic abutment crown under an existing PRDP using CAD/CAM technology. ${ }^{5}$ Yoon et al. used patient's existing cast and chairside CAD/CAM scanner for a retrofitted surveyed crown in tooth supported PRDP. ${ }^{6}$

This clinical report describes a technique to convert fractured metal-ceramic surveyed crown into a complete contour zirconia surveyed crown for an existing PRDP using CAD/CAM.

\section{Case report}

A 62-year old man diagnosed with rectal cancer was under anticancer treatments. He wanted an instant and simple treatment plan for fractured metal-ceramic

Copyright@ 2015 The Korean Academy of Stomatognathic Function and Occlusion. (c) It is identical to Creative Commons Non-Commercial License. 
surveyed crown (Fig. 1). No fracture was observed in clasp engaging area. The patient did not want a surveyed crown due to a higher risk of fracture or chipping. The fitness between the existing PRDP and fractured metal-ceramic surveyed crown was verified to ensure adequate retention and support.

An elastomeric impression of the fractured metalceramic surveyed crown was made using polyvinylsiloxane (Honigum; DMG., Hamburg, Germany). A preliminary cast was prepared with Type IV dental stone (Suprastone; Kerr Co., Orange, CA, USA). A definitive impression was made for the complete contour zirconia surveyed crown with polyvinylsiloxane after old prosthesis removal and abutment preparation. A definitive cast was also made with Type IV dental stone.

Using a digital scanner (Identica; Medit Co., Seoul, Korea), the preliminary and definitive casts were scanned (Fig. 2). The metal-ceramic surveyed crown shape was duplicated into the complete contour zirconia surveyed crown by the supplied software (Exocad dental CAD; exocad GmbH exocad GmbHExocad GmbH., Darmstadt, Germany) (Fig. 3). The design information was transferred to a milling machine (ZENOTEC T1; Wieland Dental., Pforzheim, Germany), and complete contour zirconia surveyed crown was milled from the zirconia block (Zenostar Zr Translucent; Wieland Dental.).

After the completion of the milling procedure, the complete contour zirconia surveyed crown was stained with a coloring solution (Zenostar Color Zr; Wieland Dental.) and sintered in a furnace (DentaStar M2 plus; Thermo-Star GmbH., Aachen, Germany). The definitive complete contour zirconia surveyed crown was adjusted on the cast and polished using a zirconia polishing kit (Zenostar polishing kit; Wieland Dental.) (Fig. 4).

The definitive complete contour zirconia surveyed crown was evaluated with polyvinylsiloxane fit checking paste (GC Fit Checker; GC Dental Industrial Corp., Tokyo, Japan) to verify the fit to the existing PRDP (Fig. 5). The complete contour zirconia surveyed crown was luted using a resin-modified glass ionomer cement (Vitremer; 3M Dental Products., St Paul, MN, USA) (Fig. 6). The patient was satisfied

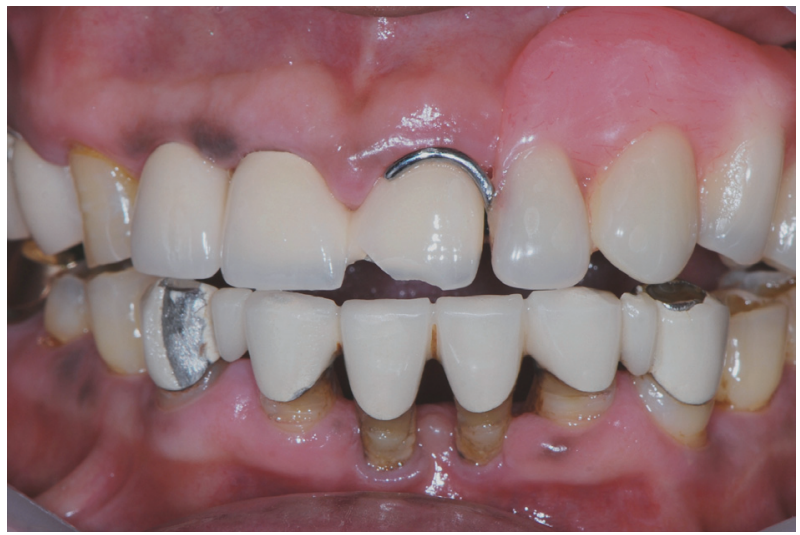

Fig. 1. Adequate fitness between the existing PRDP and fractured metal-ceramic surveyed crown.

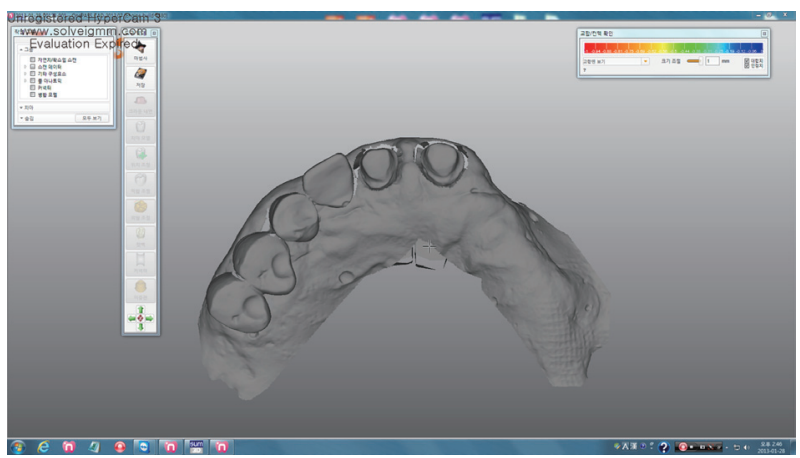

Fig. 2. Scanned image of prepared maxillary central incisors from definitive cast.

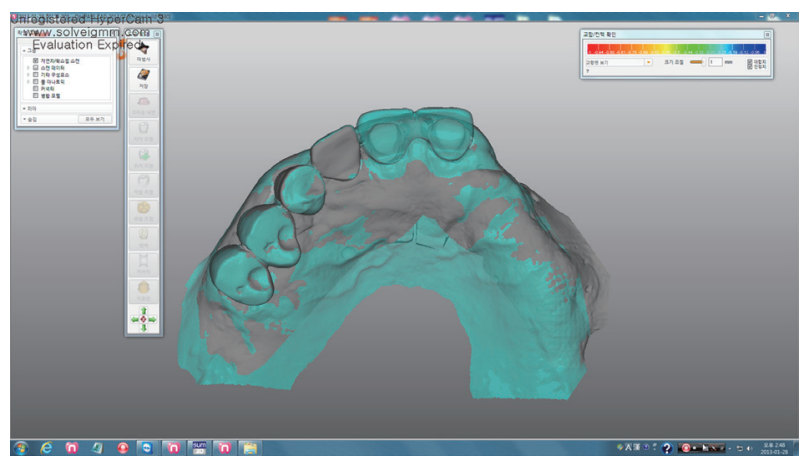

Fig. 3. Superimposed images of preliminary and definitive casts.

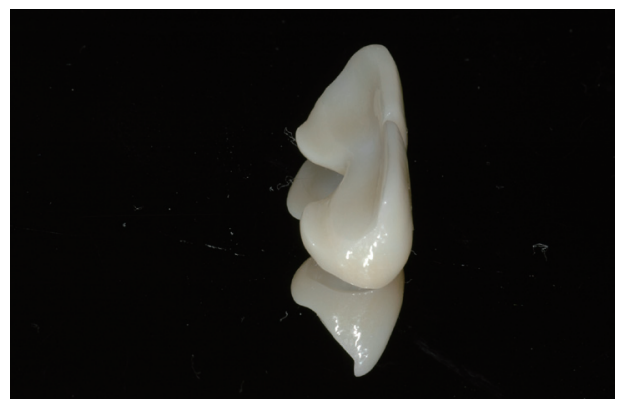

Fig. 4. CAD/CAM complete contour zirconia surveyed crown. 


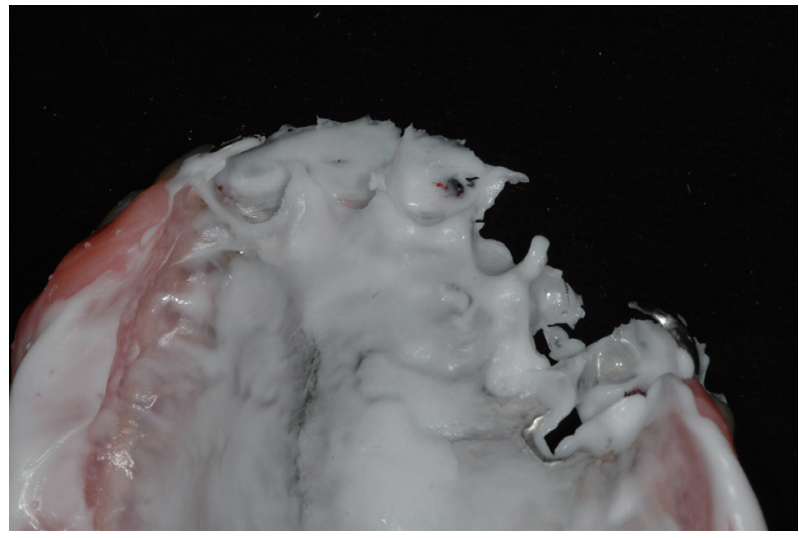

Fig. 5. Verification of the fit of definitive complete contour zirconia surveyed crown to the existing PRDP.

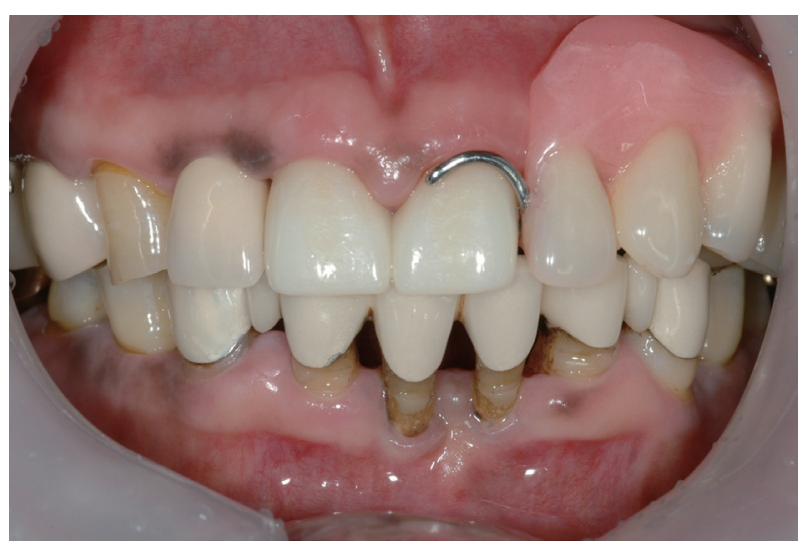

Fig. 6. Good adaptation between CAD/CAM complete contour zirconia surveyed crown and existing PRDP.

with the new complete contour zirconia surveyed crown and existing PRDP for 1 year. No clinical complications were observed during the follow-up period.

\section{Discussion}

With CAD/CAM technology, perfect adaptation between the new complete contour zirconia surveyed crown and existing PRDP was achieved, and the patient didn't show any discomfort during 1 year follow-up period.

The advantage of this technique is replicating morphology, contours, undercut, and rest seat of the old metal ceramic surveyed crown without composite resin pattern. While fabrication of composite resin pattern with PRDP adaptation is technique sensitive and needs precise and accurate adjustment, scanning of a cast is a simpler and more precise method. The other advantage of this technique is the prevention of veneering porcelain fracture or chipping. Although, in this case where the existing PRDP was a distal extension type and the fractured crown was a distal abutment, complete contour zirconia surveyed crown reduced the risk of fracture and chipping.

However, complete contour zirconia surveyed crown exhibited poor esthetics because of its low translucency. Moreover, possible disadvantage of this technique includes limitation of usage and required modification when ceramic fracture is extended to the contact area of the clasp. In such case, the fractured area needs to be restored with composite resin using patient's PRDP before impression taking.

\section{Conclusion}

The conversion of fractured metal-ceramic surveyed crown into a complete contour zirconia surveyed crown by using CAD/CAM technology for an existing PRDP under anticancer treatments is described. This technique provided a perfect adaptation between the new complete contour zirconia surveyed crown and existing PRDP. Although low translucency of zirconia calls for more esthetic needs, complete contour zirconia surveyed crown by using CAD/ CAM technology is a potential alternative to retrofit the existing PRDP framework.

\section{References}

1. Hansen CA, Russell MM. Making a crown to fit accurately under an existing removable partial denture clasp assembly. J Prosthet Dent 1994;71:2:206-8.

2. Macpherson JR, Evans DB. Fabricating crowns to fit existing removable partial dentures: an illustration of two techniques. J Prosthodont 1993;2:199205.

3. Jackson AD, Butler CJ. Fabrication of a new crown and provisional to an existing removable partial denture. J Prosthodont 1995;4:200-4. 
4. Elledge DA, Schorr BL. A provisional and new crown to fit into a clasp of an existing removable partial denture. J Prosthet Dent 1990;63:541-4.

5. Marchack BW, Chen LB, Marchack CB, Futatsuki Y. Fabrication of an all-ceramic abutment crown under an existing removable partial denture using
CAD/CAM technology. J Prosthet Dent 2007;98: 478-82.

6. Yoon TH, Chang WG. The fabrication of a CAD/ CAM ceramic crown to fit an existing partial removable dental prosthesis: a clinical report. J Prosthet Dent 2012;108:143-6. 


\section{항암치료 중인 환자에서 파절된 금속-도재관을 CAD/CAM으로 제작된 complete contour zirconia surveyed crown (완전한 윤곽을 가진 지르코니아 써베이드 전장관) 보철 수복: 증례 보고}

이선기 ${ }^{1}$, 양홍서 ${ }^{1}$, 박상원 ${ }^{1,2}$, 윤귀덕', 임현필 ${ }^{1 *}$

${ }^{1}$ 전남대학교 치의학전문대학원 보철학교실, ${ }^{2}$ 전남대학교 미래형생체부품소재 RIS 사업단

본 증례는 기존의 국소의치에서 파절된 metal-ceramic surveyed crown을 complete contour zirconia surveyed crown 으로 전환하는 간단하고 편리한 CAD/CAM 기술을 보고하고 있다. 항암치료를 받고 있는 환자의 기존 metal-ceramic surveyed crown 외형, 형태학적 특성, 레스트 시트를 complete contour zirconia surveyed crown으로 제작하는 복제 기 법에 대해 보고한다.

(구강회복응용과학지 2015;31 (1):45-9)

주요어: complete contour zirconia surveyed crown; 파절된 metal-ceramic surveyed crown; CAD/CAM ; 기존의 국소 의치; 항암치료 